\title{
Assessment of Different Bio-pesticides for Management of Fruit Borer in Tomato (Lycopersicon esculantum L.)
}

\author{
Ram Prawesh Prasad", R. K. Mandal and Savita Kumari \\ Krishi VigyanKendra, Bhagwanpur Hat, Siwan (Bihar)-841408, (Dr.Rajendra Prasad Central \\ Agricultural University, Pusa, Samastipur, Bihar) 848125, India \\ *Corresponding author
}

\section{A B S T R A C T}

Keywords

HaNPV, Bt, NSKE,

Helicoverpa

armigera, Insect/

pest incidence,

Tomato and BCR

Article Info

Accepted:

20 July 2020

Available Online:

10 August 2020
Tomato (Lycopersicon esculentum) is the world's second important vegetable crop known as protective food because of its special nutritive value and widespread production An experiment was conducted to Assessment of different Bio-pesticides for management of fruit borer in Tomato(Lycopersicon esculantum L.). The on farm trial were carried out in farmers field of 05 different location of Bhagwanpur hat Block of Siwan district, Krishi Vigyan Kendra, Siwan (Dr.Rajendra Prasad Central Agricultural University Pusa, Samastipur), Bihar, during the time period from November, 2015 to March, 2016. The cost ratio of was also calculated, it ranged from technological option I- Spraying of cypermethin 10EC, III--NSKE 4\% with sticker and II Bt formulation @ 500gm.per ha. at 10 days interval was higher than the farmer practices.Thus, and it was clearly showed that the technological option. I- HaNPV 250LE with jaggery 10 gm./litre of water, technological option. III-NSKE 4\% with sticker and technological option. I- Bt formulation @ 500gm.per ha. at 10 days interval was better than farmer's practices.

\section{Introduction}

Tomato (Lycopersicon esculentum) is the world's second important vegetable crop known as protective food because of its special nutritive value and widespread production. In India nearly 7.1 million tonnes of tomato is produced annually, ranking it fifth in the world, from an area of 5.4 lakh ha, placing the country at the second position globally based on its area of production (Arora et al., 2012). This crop is severely attacked by various insect pests viz., fruit borer, H. armigera (Hub.); whitefly, Bemisia tabaci (Gennadius); aphid, Aphis gossypii (Glover); leaf eating caterpillar, Spodoptera litura (Fabricius); American serpentine leaf miner, Liriomyza trifolii (Burgess) and red spider mite (Tetranychus urticae) Ignacimuthu, S. (2007). Among these, fruit borer, $H$. armigera is an important pest responsible for major yield loss in tomato. $H$. armigera has attained the status of national pest in recent years in the form of economic damage caused to different agricultural crops throughout India. Number of synthetic organophosphate insecticides has been recommended for its effective control from 
different parts of country Mote et al., (1975). The safe and effective pesticides should be recommended for control of this pest. With this objective now a day's bio- pesticides have been recognized in biological approach of pest management. To control the borer, many preventive measures have been reported across the world. Among these, chemical insecticides can be used for effective control but they have extreme adverse effects on environment and consumers. Moreover, continuous use of chemical insecticides develops cross and multiple resistant strains in many important insect species (Geiger et al., 2010) including this fruit borer. However, to avoid the hazardous effect on ecology and ultimate consumers, now-a- days different time demanded eco-friendly control. Therefore the experiment was undertaken aiming to control the tomato fruit borer (TFB) infestation through biopesticides in ecological safe way and simultaneously to evaluate the best performing management practice among the used ones.

\section{Materials and Methods}

The on farm trial were carried out in farmers field of 05 different location of Bhagwanpur hat Block of Siwan district, Krishi Vigyan Kendra, (Dr.Rajendra Prasad Central Agricultural University Pusa, Samastipur), Bihar, during the time period from November, 2015 to March, 2016 to record the reliable data in order for assessing the comparative performance of eco-friendly management tools against Tomato Fruit Borer (TFB) infestation in ex situ condition.

\section{The technological option as were fallows-}

F.P-Spraying of cypermethin 10EC

T.O.I- HaNPV 250LE with jaggery 10 gm./litre of water
T.O.II- Bt formulation@ 500 gm.per ha. at 10 days interval.

\section{T.O.III-NSKE $4 \%$ with sticker}

The experiment was RBD design with five replications and four technological options including farmers practice. The size of a unit plot was $20.00 \mathrm{~m} \times 10.00 \mathrm{~m}$. Distance of 1.00 $\mathrm{m}$ between blocks and $0.5 \mathrm{~m}$ between the plots was maintained to facilitate different intercultural operations.

\section{Data collection parameters}

The data on percentage infestation of tomato fruits by borer was calculated at each picking by counting damage and healthy fruits in each spray application. The mean per cent fruit damage was calculated using formula:

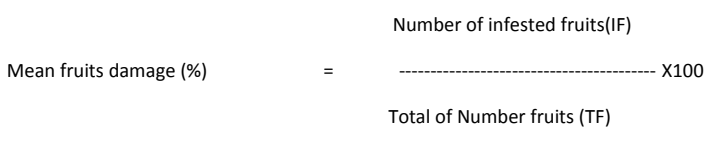

\section{Total Number of infested fruit}

The infested fruits were collected from each tomato plant during different fruiting stage (early, mid and late stage) and thereafter, number of infested fruit was counted visually.

Total No. of Infested fruits/plant $=$ Total no. of fruits in plant - number of infested fruit

\section{Number of larvae (borer) per fruit}

Firstly the infested fruits were collected from each plot. Secondly number of larvae per infested fruit was visually estimated through dissection and finally their average value was estimated by the formula as follows:

Total no. of borers per fruit

Mean number of borer per fruit

Total numbers of infested fruits plot 


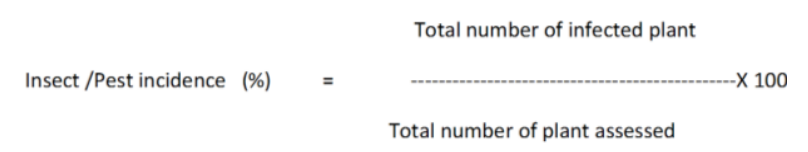

(Berger-1980)

\section{Data analysis}

The recorded data were analyzed statistically for ANOVA (Analysis of Variance) with the help of computer package program MSTAT$\mathrm{C}$ where the mean differences were adjudged by Duncan's New Multiple Range Test (DMRT) (Gomez and Gomez, 1984).

\section{Results and Discussion}

Assessment of different Bio-pesticides for management of fruit borer in Tomato (Lycopersicon esculantum L.) recorded at different intervals after first, second and third spray The results showed that all the technological options recorded significantly lowest larval population over control (Table 1). Larval population of $H$. armigera was significantly lower in all the treated plots over control. From the result of spray, by HaNPV 250LE with jaggery $10 \mathrm{gm}$./litre of water recorded least insect pest incidence $(3.67 \%)$ followed NSKE 4\% (5.33\%) and Bt formulation @ 500gm/ha. (8.0\%).

Among all technological options HaNPV 250LE with jaggery $10 \mathrm{gm}$./litre of water showed best results, whereas Other biopesticides viz., B. thuringiensis and NSKE $4 \%$ showed $5.33 \%$ and $8.0 \%$ insect pest incidence found least effective but were superior over farmers practices (control). After10 days of 2ndspray, the fruit borer population was once again recorded minimum in plots treated with HaNPV 250LE. These findings are agreement with Abhijit et al., (2012) Sherad et al., (2014).

Table.1 Impact of different bio pesticides for management practices on tomato fruit borer

\begin{tabular}{|c|c|c|c|c|c|c|c|c|c|}
\hline \multirow[t]{2}{*}{ Technology option } & \multirow{2}{*}{$\begin{array}{l}\text { No. of } \\
\text { trials }\end{array}$} & \multicolumn{2}{|c|}{ Yield component } & \multirow{2}{*}{$\begin{array}{l}\text { Disease/ } \\
\text { insect pest } \\
\text { incidence } \\
(\%)\end{array}$} & \multirow{2}{*}{$\begin{array}{l}\text { Yield } \\
\text { (q/ha) }\end{array}$} & \multirow{2}{*}{$\begin{array}{l}\text { Cost of } \\
\text { cultivation } \\
\text { (Rs./ha) }\end{array}$} & \multirow{2}{*}{$\begin{array}{l}\text { Gross } \\
\text { return } \\
\text { (Rs/ha) }\end{array}$} & \multirow{2}{*}{$\begin{array}{l}\text { Net return } \\
\text { (Rs./ha) }\end{array}$} & \multirow{2}{*}{$\begin{array}{l}\mathrm{BC} \\
\text { ratio }\end{array}$} \\
\hline & & $\begin{array}{l}\text { No. of } \\
\text { effective } \\
\text { fruits } \\
\text { /plant }\end{array}$ & $\begin{array}{l}\text { Weight of } \\
\text { fruits/ } \\
\text { plant (Kg) }\end{array}$ & & & & & & \\
\hline $\begin{array}{l}\text { F.P-Spraying of } \\
\text { cypermethin 10EC }\end{array}$ & 05 & 119.33 & 3.00 & 9.33 & 295 & 68500.00 & 295000.00 & 226500.00 & 4.30 \\
\hline $\begin{array}{l}\text { T.O.I- HaNPV 250LE } \\
\text { with jaggery } 10 \\
\text { gm./litre of water }\end{array}$ & & 203.67 & 4.750 & 3.67 & 370 & 72800.00 & 370000.00 & 297200.00 & 5.08 \\
\hline $\begin{array}{l}\text { T.O.II- Bt } \\
\text { formulation@500gm. } \\
\text { per ha. at } 10 \text { days } \\
\text { interval. }\end{array}$ & & 128.00 & 3.700 & 8.00 & 310 & 70000.00 & 310000.00 & 240000.00 & 4.42 \\
\hline $\begin{array}{l}\text { T.O.III- NSKE } 4 \% \\
\text { with sticker }\end{array}$ & & 105.33 & 2.250 & 5.33 & 319 & 68200.00 & 319000.00 & 250800 & 4.67 \\
\hline $\mathrm{SE}(\mathrm{d})$ & & 1.34 & 0.53 & 0.67 & 3.24 & & & & \\
\hline $\mathrm{CD}(\mathrm{P}=05)$ & & 2.95 & 1.15 & 1.75 & 7.03 & & & & \\
\hline
\end{tabular}

The input and output prices of commodities prevailed during the research year of on farm trail were taken for calculating yield, cost of cultivation, net return and benefit cost ratio (Table 1). The net return from technological option. I- HaNPV 250LE with jaggery 10 gm./litre of water, technological option. IIINSKE 4\% with sticker and technological option. II- Bt formulation@ @ 500gm.per ha. at 10 days interval was Rs. 297200 to Rs. 250800 
and240000 while the net return from Spraying of cypermethin 10EC (farmers practices) was Rs. 226500. It means that net return from technological option I, III and II was higher than the farmer practices. The cost ratio of was also calculated, it ranged from technological option I- Spraying of cypermethin 10EC (5.08), III--NSKE 4\% with sticker (4.67) and II Bt formulation@500gm.per ha. at 10 days interval (4.42) was higher than the farmer practices (4.30). Thus, and it was clearly showed that the technological option.I- HaNPV 250LE with jaggery $10 \mathrm{gm} . /$ litre of water, technological option. III-NSKE 4\% with sticker and technological option.II- Bt formulation@ $500 \mathrm{gm}$.per ha. at 10 days interval was better than farmer's practices. Similar result has been reported by earlier by Karabhantanal, et al., (2013) and Majumdar, et al., (2015).

In conclusion technology option $1^{\text {st }}$ (HaNPV 250LE with jaggery $10 \mathrm{gm}$./litre of water) performed bitter in the term of effectiveness and economics where as rest of the from technological option. III-NSKE 4\% with sticker and technological option.II- Bt formulation@ $500 \mathrm{gm}$.per ha. at 10 days interval at par. The disease incidence was also less.

\section{References}

Arora S, Kanojia AK, Kumar A, Mogha N, Sahu V (2012). Biopesticide formulation to control tomato lepidopteran pest menace. Curr Sci 102: 1051-1057

Ignacimuthu, S. (2007). Insect Pest Management. Meeting Report. Current Sci., 92: 13361337.

Mote, U. N. and Pokharkar, R. N. (1975). Chemical control of tomato fruit borer $(H$. armigera). Journal of Mahtama phule Agricultural University, 6: 69-70.
Geiger, F., Bengtsson, J., Berendse, F., Weisser, W.W., Emmerson, M., Morales, M.B., Ceryngier, P., Liira, J., Tscharntke, T., Winqvist, C. and Eggers, S. (2010). Persistent negative effects of pesticides on biodiversity and biological control potential on European farmland. Basic and Applied Ecology. 11(2): 97-105

Berger, R,D(1980) Measuring pest incidence,-In: Teng, P. S., S. V. Krupa (eds.):Crop loss assessment, Proc.E.C Stakman Commen. Symp. Misc. Publ.7, Agric. Exp. Stn. pp. 28-31.

Gomez, K.A. and A.A. Gomez. 1984. Statistical Procedures for Agric. Res. 2nd Edition, John Wiley and Sons, New York, USA. pp. 97-111.

Abhijit, K.P., Krishnaiah, K. R. and Sudhakar, K. (2012). Studies on some insecticides with novel mode of action for the management of tomato fruit borer (Helicoverpa armigera). Journal of Crop and Weed, 8(2):126-129.

Sherad and Kalyan, k. (2014) Efficacy of botanical extracts and a chemical pesticide against tomato fruit borer, Helicoverpa armigera (Lepidoptera: Noctuidae). Sarhad J. Agric. 29 (1): 93-96.

Karabhantanal, S. and J. Awaknavar. 2013. Bio intensive approach for the management of tomato fruit borer, Helicoverpa armigera (Hubner). Pest Manag. Hort. Ecosys. 18: 135-138.

Majumdar, A. and M. Powell. (2011) Net House Vegetable Production: Pest Management Successes and Challenges. J. Nat. Assoc. Country Agric. Agents. 4(1): 355-363.

Majumdar, A., Chambliss, A., Mastin, W. and Carpenter, S. (2015). High Tunnel Pest Exclusion System: Laboratory and Field Experiences. J. Nat. Assoc. Country Agric. Agents.. 8(1). 487.

\section{How to cite this article:}

Ram Prawesh Prasad, R. K. Mandal and Savita Kumari. 2020. Assessment of Different Bio-pesticides for Management of Fruit Borer in Tomato (Lycopersicon esculantum L.). Int.J.Curr.Microbiol.App.Sci. 9(08): 2220-2223. doi: https://doi.org/10.20546/ijcmas.2020.908.254 